\title{
THE INTERSECTION OF GAY STREET and Straight Street: Shopping, Social Class, and the New Gay VisibiLITY
}

\author{
JOSHUA GAMSON \\ University of San Francisco
}

If you turned on your television in the summer of 2003, you most likely encountered the Fab 5. Their TV show, "Queer Eye for the Straight Guy," had quickly become a hit for the cable network Bravo, whose partner NBC then also picked up the program. In each episode the Fab 5 take a slovenly heterosexual man and give him and his space a makeover, just in time for the straight guy to impress his girlfriend, potential girlfriend, wife, or womankind more generally. The Fab 5, each of whom has a special expertise-grooming, culture, food and wine, interior decorating, and fashion - are funny, warm, and witty. Straight men thank the Fab 5 profusely, praise them to their friends, and hug them; straight women gush about and around them. They have appeared on NBC's "The Tonight Show with Jay Leno," "Oprah," the MTV Video Music Awards, and the season premiere of the NBC sitcom "Good Morning, Miami." They have been parodied on Fox's "Mad TV," and inspired a Comedy Central take-off, "Straight Plan for the Gay Man." "Queer Eye" has often drawn over 3 million viewers, more than twice the number of viewers any Bravo show had previously attracted, often beating out the major networks for viewers; when NBC first aired it, the show drew 7 million viewers and tied for first in its time slot among 18-49-year-old viewers (Weinraub and Rutenberg 2003). In 2004, NBC ran a "Queer Eye" marathon on Super Bowl Sunday. "Queer Eye for the Straight Girl," a spinoff, will begin airing in 2005. Bravo has sold the show to twenty countries (della Cava 2004). 
The first gay male dating program, Bravo's "Boy Meets Boy," ran the same summer and became that company's second most watched show ever. In it, a gay bachelor named James considered fifteen suitors for a week, some of whom turned out to be - gasp! straight. They went on little, romantic dates, and told each other how nice and attractive they were; they frolicked in the pool in their ranch-style house in Palm Springs; James' best girlfriend Andra grilled and befriended and judged the candidates. At the end of each episode, James invited some boys to stay and others to leave, and eventually James and his first choice, the decidedly gay Wes, walked off into the sunset for an all-expenses paid vacation to New Zealand. In their debriefings, the straight contestants spoke of the excellent gay friends they made, of how much they learned from having to hide their "true" sexuality, and how happy they were to be part of a program that showed gay men and straight men aren't all that different.

So-called "reality" television—first talk shows, then "The Real World"-were the earliest sites of routine gay visibility on television (Gamson 1998; Gross 2001; Walters 2001). More recently, reality television has become the hotbed of a new kind of gay visibility. Bravo's reality programs, for example, have produced a fascinating reversal of fortunes, in which gay men are not only celebrated but emulated and admired, and in which straight men are rewarded for seeming more like gay ones. Historically, it has been the queer who, by virtue of his presumed proximity to womanliness, has been held up as the model of what a real man should not be; sissies, for instance, are instructed in how to behave more like "men," with often violent repercussions if they fail (Rottnek 1999). You can turn on your television right now and watch as the queer, even the sissy, becomes the model of what a man should be, and as straight men are instructed by queers in how to appear gayer, with the reward usually the admiration of heterosexual women. Historically, it was the gay person who spent some timeshort, long, or forever - in the closet, lying and dissembling and pretending to be straight in order to win acceptance (Seidman 2002). You can turn on your television right now and watch as straight guys go into the closet—okay, just for a week—lying and 
dissembling and pretending to be gay in order to win the acceptance of a gay man and a $\$ 25,000$ prize.

In both cases, the spectacle includes reconciliation, almost a lovefest, between gay and straight men brought about by the apparent gaying of the straight. This is quite a sight. In his debriefing, Michael, one of the straight contestants on "Boy," reported that he took from the experience the revelation that gay people are "generally of a higher caliber sort of person," more "sincere" and "in touch, you know, with their emotions." Dan, in his debriefing, talks about how much he learned about "the gay culture," and about the difficult experience of "trying to fit in when you have to pretend to be something you're not," which, he notes, parallels the experience of many of the gay men he met on the show. Jim, in his debriefing, notes similarly how his life on the show was a "mirror image" of the gay closet, and that "I just have a feeling I'm going to be seeing things through a different eye." For its part, "Queer Eye" opens with images of two street signs, and locates the show precisely at the intersection of Gay Street and Straight Street. It's a happy location. "Queer Eye" drips with expressions of gratitude for gay men - toasts, usually - and always includes the new spectacle of straight men in emotional embraces with gay men.

\section{Making Sense of the New Gay Tele-Visibility}

Something important and strange is going on when people who just a few years ago reviled you decide instead they want to be you, or at least dress like you. What is going on here? What kind of visibility is this exactly? How and why do we get this "gay is great" form of visibility? On one level, the reconciliation and celebration of gay men on television is just another step on a rapid march of lesbians and gay men into the American cultural mainstream. Not very long ago at all, one of the main problems facing lesbians and gay men was lack of cultural visibility (Gross 2001). It was hard to fight for rights or liberation when your existence was unacknowledged, or so narrowly and nastily defined that you hardly seemed deserving of much more than imprisonment, selfhatred, psychiatric treatment, or suicide. Over the past decade, 
that has rapidly changed, largely through an explosion of gay visibility on television. The rapid movement of gay men into television visibility began largely when the character of Ellen on "Ellen" came out of the closet and the sky did not fall, and was pushed by the critical and ratings dominance of "Will and Grace"; the successes of "Ellen" and "Will and Grace" broke down advertiser fears of gay images. The visibility trend then fed itself the way most television trends do: networks tried to copy each other's successes, and gay people suddenly went from shunned to popular. Recent years have seen numerous sitcoms with gay male characters; dramas with recurring lesbian or gay characters, and the first prime-time lesbian soap opera, Showtime's "L Word"; a slew of reality shows with lesbian or gay participants, including first "Survivor" winner Richard Hatch; homosexual cartoon characters; and not one but two programs on American television with the word "queer" in the title. A gay male couple won "The Amazing Race," and Ellen DeGeneres reemerged with an afternoon chat show. Gay and lesbian teenagers continue to pepper reality programming on shows like MTV's "Real World," and Showtime's "Freshman Diaries," and as if that was not enough, last year Madonna tonguekissed Britney Spears on national television. As Suzanna Danuta Walters puts it, in recent years "the love that dare not speak its name became the love that would not shut up" (2001: 11). We have certainly finished with the slow, uphill push for visibility and are now in a rapid downhill roll into the mainstream of American culture.

Gay men in particular seem to be getting more and more "normal" by the minute, increasingly indistinguishable from heterosexuals, and the logic of punishing people for their desires, identities, and relationships seems to be making less sense. This is a radical promotion on a ladder that has only recently been set up: first, gay people were visible as curiosities, focal points of social controversy or butts of jokes; then, humanized on talk shows as experts in their own experience, and later as screamers, cheaters and hair-pullers (Gamson 1998); then, on sitcoms and dramas, shown to be sort of separate but equal, with our own gay perspectives, problems, and senses of humor (Walters 2001). Now, in the 
next flattering stage, gay men are represented as role models for straight people. This all sounds like a lovely sort of progress, and in many ways it is; one might reasonably prefer to be valorized than demonized, especially if one is credited with being unusually witty and attractive.

The televised rituals of emulation that take center stage on, for instance, "Boy Meets Boy" and "Queer Eye for the Straight Guy," however, may not necessarily be signs that American culture is opening up, or of a growing admiration for gay men in American society. The trend in opinion is certainly in the direction of greater acceptance of civil rights for gay people, but it's a stretch to say that a majority of Americans see gay men as role models. Indeed, most Americans still report that they think homosexual behavior is immoral (Herek 2000). I will argue that these rituals are more accurately understood as a means to close down the challenges and anxieties posed as gay men are "mainstreamed," and that contemporary gay tele-visibility gets its shape mainly from the routines of television.

The very visibility, mainstreaming, and normalizing of homosexuals on television has set in motion a new set of problems and a new set of conversations. We can understand the current wave of television visibility as a sort of anxious call-and-response conversation about the blurring of lines between gay men and straight ones. The problem of gay-straight differences has moved into the spotlight in a new way. Earlier, the differences between gay and straight were assumed to be extreme, and the lines between gay and straight clear; the major question was whether we should be treated with tolerance, condemnation, hostility, or love. But now that, according to television, gay is no longer so "abnormal" and "different," how can you tell the difference between a gay man and a straight one? Put in more general terms: If heterosexuality depends in part on its opposite, and homosexual difference is no longer so reliable, what happens to the straight man and his supposed superiority?

Television has raised the question, and television is also offering its own quite specific answers, ones that fit the exigencies of the television business. Commercial television producers, in par- 
ticular, are clearly driven by two major interests: avoiding financial risk and providing an environment that advertisers perceive as friendly to consumption (Gitlin 1983). These interests give the new gay visibility its particular shape. Genres, first of all, offer an efficient risk-reduction mechanism: they make production simpler, since a conventional format is already in place; they make the product recognizable to audiences, since they obey a familiar formula (Swidler et al. 1986). Working within a genre, and tweaking already successful genres for novelty, makes sense in a high-risk cultural business. Genre conventions, therefore, crucially shape the kind of visibility we get on television for stigmatized or marginalized groups. Second, producers and executives also seek to provide an environment that advertisers perceive as friendly to consumption. At times, such an environment is pursued via censorship or self-censorship: refusing to air something, or deciding not to produce programming, that advertisers might think would disturb or bring down viewers (Croteau and Hoynes 2001). At other times, it is pursued by producing programming that serves to actively cheerlead for consumption. Gay men's stereotyped affinity for home, leisure, and body professions makes them an especially good fit for such programming. The small ways in which gay men are different from straight men, in this consumption-friendly model, can be useful to straight men. Gay men become master shoppers and instructors in social class, teaching straight men to become more effective heterosexuals: by becoming more effective consumers and more "classy," straight men are not emasculated but made more desirable to women. It is by this narrowing logic that gay men are to be emulated rather than derided.

Let me show you what I mean.

\section{The Dating Genre: Normal and Normaler}

One key proposition of current television discourse is that, contrary to dominant portraits of them as abnormalities of sexuality and gender - prone to promiscuity and effeminacy — gay men are quite "normal." This is especially useful in reality programming, which is notoriously exploitative, setting people up in this 
way and that with cameras rolling (Gamson 1998). Positioning programs as counter-stereotypical, sympathetic portraits with educational value allows television corporations to promote their gaybased reality shows as socially redeeming and progressive. Even without such claims, however, as gay men are imported into existing genres to give them a distinctive little twist, they get pulled along by the genres' conventions. In the case of dating shows, this means getting pulled along a current that heads straight for middle-class propriety.

The normalization of gay men is especially pronounced when the genre conventions emphasize core norms of the culture, such as the pursuit of monogamous romance as a means of organizing one's life. The genre of find-your-spouse dating shows that serves as the template for "Boy Meets Boy" - not shows like "Temptation Island," but shows like "The Bachelor," "The Bachelorette," and even "Joe Millionaire" - are very much about enacting a middle-class, 50s-style sexual script. The stated goal of the shows is typically to marry off a couple of their participants. Suitors compete for the affections of the pursued, each offering his or her version of courtship; there may be some smooching, but the presentation of sex is very tame, as though the participants are saving themselves for marriage. Often, friends or family members meet the potential spouse and help the protagonist choose an "appropriate" partner. The participants are expected to conform to the basic norms of middle-class coupling, and those who don't conform do not fare well; "players" get booted off, for instance, since they don't fully conform to monogamy norms. The central symbols are borrowed from middle-class romance, as well: there is much exchanging of roses, drinking of champagne in candlelight, heart-tohearts in moonlight, and the like. The trajectory of the show, from week to week, is to gradually narrow the pool until all that remains is the perfect couple, who will be rewarded with a honeymoon-like trip, interviews on "Good Morning America" and features in Us magazine, and true love. On some shows, the result is an actual bended-knee proposal of marriage. You half-expect the hosts to offer the couple a free baby.

"Boy Meets Boy," Bravo's dating show, is an excellent exam- 
ple of how such genre conventions can shape visibility, giving gay men a big push towards "the normal." When gay men are brought into the dating genre, it is mainly to provide a bit of noveltygiving the show a shot at standing out, but also offering the comforting familiarity of a tried and true genre. The result is, quite predictably, a heavy emphasis on how "normal" gay men are in their desires and behaviors. Normal, on this show as in the genre more generally, is indicated by signs of middle-class membership and conventional masculinity. For instance, Bravo press materials describe the main character, James, as "a handsome, 32-year-old administrator in the human resources department of a law firm" (Bravo, "Boy Meets Boy") — middle in every way except perhaps appearance, where he is above average. James himself told the Advocate that he appeared on the show not just to find a man, but to demonstrate that "we are normal people with normal jobs [and] normal friends, looking for love and happiness just like everyone else" (qtd. in Andreoli 2003). On the show itself, he declared that "we're all looking for love, we're all looking for romance, we're all looking for relationships," and later peevishly mentions his hope that "just one of these fifteen [guys] was actually going to be just a normal person." His "mates" on the show repeat much the same thing. "I want my partner, I want my house, I want my kids, I want my dogs," one of his suitors told James. "I just want to have my normal life." The eventual winner, Wes, declared that he "wanted America to see the truth about who we are," to see "real gay men." "There have always been these stereotypes of gay men not being athletic, gay men not being masculine," Wes said, "and this show blows that out of the water." The show, that is, presents gay men as gender-normal seekers of monogamous love relationships and middle-class domesticity.

\section{Can You Tell The Difference?}

If on "Boy Meets Boy" and on other norm-celebrating programs gay men are now paragons of normality, on this program, and on mainstreaming television more generally, a certain anxiety is evident about what this means for straight men. If gay men are just like 
straight ones, how can you tell the difference? And if you can't tell the difference, what happens to straight men's claim to be "real" men, and the attendant privileges of what some theorists have called "hegemonic masculinity" (Connell 1987)? The mainstreaming of gay men on television puts this question on the table, and genre conventions often push them right to the center. For instance, dating shows are structured as "games," and its participants are "contestants." One of the ways producers often attempt to make the game interesting is by offering a twist: on "Joe Millionaire," the women competing assumed the object of their desire was a millionaire, when in fact he was not; on "For Love or Money," the finalists chose between money or the woman, and thought she didn't know it but she did; and so on. Built into such games is an incentive for deception, and much of the programming is therefore devoted to the question of who is for real and who is just trying to win the game; built into the genre is a game of telling the difference between the "real" and the "imposter."

This difference-telling game is actually a longstanding format in another reality genre, the daytime tv talk show. That genre, at least in its Ricki Lake/Jerry Springer versions, makes its money from staging emotional conflicts over norms, and from displaying non-normative issues, people, and behaviors; triggering discussions about the line between "normal" and "abnormal" is the genre's bread and butter (Gamson 1998). One of their central early roles of gay men and lesbians on talk shows was to raise the question of whether you can tell the difference between a gay person and a straight one. In the old days, that was raised by shows on feminine lesbians and butch gay men, but it has recently reemerged in a slightly revised form. Now, it takes off from the recognition of new problems raised by the mainstreaming of gay men. As Ricki Lake herself put it on a show in September called "How Straight Is He?," "Today, the lines between gay guys and straight guys is so confusing sometimes it's impossible for a girl to tell.... In today's world, gay people are into the mainstream on television and in everyone's hometown. This makes the world a lot more interesting and open, but in some cases it can make the world a bit more puzzling" (Ricki Lake Show 2003). 
On "Boy Meets Boy," the twist, of course, is that not all of the contestants for the gay man's hand are actually gay. A central theme of the show becomes the question of "can you tell who is gay and who is straight?" Bravo boasts in its press materials that the program serves the socially productive role of provoking "debates that challenge the socially preconceived notions of what is considered gay and straight behavior" (Bravo TV, "Boy Meets Boy") and while that may be the case, it is almost certainly a result of needing "a twist" rather than its impetus. This twist leads, on the one hand, to the spectacle of straight men closeting themselves and the subsequent revelations that life in the closet is difficult and that gays and straights are quite similar. On the other hand, the twist leads to an almost obsessive attention to telling the difference between gay and straight, along with the sneaking suspicion that even heterosexuality involves role-playing. "Appearances aren't always what they seem," a female voiceover announces ominously. It is James' job, she says, to put "his gaydar to the test," distinguishing the gay from the straight. (A FOX knockoff, "Playing It Straight," also made gaydar its premise. In that show, a woman must select a suitor from a group of fourteen men, some of whom are gay. If she chooses a gay man passing as straight, the man wins a million dollars; if she chooses a straight man passing as straight, the two of them split the million dollars.) This difference-telling game, of course, would be no fun - and therefore not a great attraction to audiences - if it were easy to do. "I really learned that you have no idea who is and who isn't," said one booted contestant, identified as "Brian A., Straight," in a succinct summary of the show's pitch, and its threat.

\section{We're Here, We're Queer, and We're Taking You Shopping: Gay Men as Model Consumers and Class Instructors}

If "Boy Meets Boy," talk shows, and much other television programming have raised and played with the question of how you tell the difference between the gay and straight, one might consider "Queer Eye for the Straight Guy" as television's proposed answer. Here, again, it is worth noting how visibility is 
shaped by genre conventions and by the broader interests of commercial television in, well, commerce. The makeover genre, of which "Queer Eye" partakes, is arguably the most consumptionfriendly genre on television. The makeover program is all about change, of course - typically some version of a change from "ugly" to "beautiful," but also often from "tacky" to "classy." The genre typically tells stories, first, of self-improvement pursued through goods and services, and rewarded with a repaired relationship to oneself or to others; the "new you" gets accolades from people who seem to love you more now (with your new haircut/nose/ breasts) than before. Second, in its typical format—on tv talk shows, and on recent programs like "Extreme Makeover" or "Trading Spaces"- the makeover moves you "up" a class in appearance. On talk show makeovers, for instance, the usual format is to take someone who appears "slutty" or "trashy," and transform her into a more "refined," "classy" woman through hair, makeup, and dress. The genre dramatizes class mobility through proper consumption.

Gay men, who have long been stereotyped as being especially talented in fashion, hair, make-up, and interior design, are a natural fit for the genre. When Bravo imported gay men into the makeover genre, it simply slotted the Fab Five into the existing genre conventions: their job is to provide the skills and products for unrefined, unattractive men to become refined, attractive gentlemen. It is for this that the gay men are celebrated: they are master shoppers, and excellent instructors in participation in upper middle class urban culture. This is the basis for the reconciliation between gay and straight.

"Queer Eye" offers an answer to the question of whether and how gays and straights differ, proposing that you can tell a gay man by how well he shops (especially for home and body products). It takes the anxiety generated by the mainstreaming of gay men - if they're normal, what am I? - and weds it to the project of promoting consumption. The differences between gay men and straight ones are minor at worst, and at best helpful to straights, the show suggests. Before his makeover, the straight guy has neither the incentive nor the skills to shop right; by the end of the episode, he has both. The Fab 5, significantly, know more about 
being upper-middle class than their straight subjects, and can therefore teach others. One reward of becoming more like a gay man, according to the show, is that you will move up notch, class-wise, through a set of lessons in the consumption habits and cultural customs of the upper middle classes, especially the hip urban upper middle classes. Straight men are to emulate gay men because there is much to gain: if you become "gayer," you will become "classier". The show's opening sequence features "before and after" poses: a man in flannel becomes a man in a suit; a man in bland plaid becomes a man in glasses and a tie; a nondescript man in a La-Z-Boy becomes a turtlenecked sophisticate in a mid-century leather chair. The Fab 5 routinely comment on their pre-fabulous surrounding by pointing out markers of lower class cultures. "Staten Island, the aluminum siding capital of the world," says fashion guy Carson; "the land of maintenance-free architecture," interior-design guy Thom adds. "Do you have bad credit or just bad taste," Carson asks a pre-queer straight guy, who is also criticized for shopping at the discount drugstore Duane Reade and for the "bridge and tunnel" aspect of his hairstyle. Carson promises to bring the man closer to the "level" of his "pretty sophisticated" girlfriend. "This is not how you hang art," Thom comments on another man's art, then adds, laughing, "this is not really art." Another straight participant mentions, in his kitchen, that "these are uncertain times." Ted, the food and wine guy, considers the comment. "I don't know if they're uncertain enough to eat salmon out of a can," he says. Bravo's press materials make the social class "upgrade" content explicit, describing the Fab 5 as "an elite team of gay men who have dedicated their lives to extolling the simple virtues of style, taste, and class," whose mission is "to transform a style-deficient and culture-deprived straight man" into a "freshly scrubbed, newly enlightened, ultra hip man to teach him about "wines that don't come in a jug" and "why hand soap is not a good shampoo (or vice versa)" (Bravo TV, "Queer Eye for the Straight Guy"). Indeed, the shopping sequence is one of the anchors of the show, which is filled with shots of stores (Pottery Barn, Portico, Yves Saint Laurent) and with brand mentions (KMS, Modern Organic Products, Norelco). 
The "gaying" of the straight guy, ironically, increases his effectiveness as a heterosexual. The show is careful to demonstrate that straight men need not be threatened by the blurred boundaries, since the show ritualistically demonstrates that the reward of becoming gay-ish is the affections of a good woman. Masculinity remains intact, just revised. If you follow the instructions of the Fab Five, each episode demonstrates, you will become a more successful heterosexual man. What the straight women on the show want, it turns out, is a well-groomed, neat man, whose care for himself will be interpreted as a gift to women. As in all makeover shows, the made-over receives much love and approval for his new self, and in this case it is almost always from a woman who seemed to have one foot out the door before the makeover. No wonder the straight guy is always so grateful.

\section{Winners and Losers}

Because of television's genre conventions and the pursuit of advertiser-friendly programming, I have suggested, gay men are being rapidly assimilated as "normal" on television. The anxiety about how you can tell gay from straight is met with the suggestion that gay men are master consumers and class instructors. This is the specific way in which gay men are assimilated as "normal." What gets lost and what is gained in this celebration of hypernormal, consumption-savvy gay men? Who wins and who loses? It is in some ways very flattering, and certainly an improvement over the representation of gay men as victims or villains. But it is very, very narrow in class, gender, and racial terms. Those most served by this type of gay male visibility, it should be noted, are those seeking new market segments to whom to sell body, home, and leisure goods and services. If straight men become more like these gay ones, they will be a newly eligible for ads and purchases of products previously marketed to women only-as one commentator recently remarked, men will be the new women (Stanley 2003).

It is not only straight-run companies who benefit from this new gay visibility. The images favored by commercial television, 
finally, also dovetail with the images put out over the last two decades by gay entrepreneurs, who have been actively promoting and selling the notion that gay men are master consumers, and should be valued politically because they are a valuable market niche. Gay businesses, marketing companies, and media have been pursuing this normalization-via-consumption over the last two decades (Chasin 2000; Sender 2004). Media scholar Katherine Sender notes, for instance, how The Advocate's positioning as "an appropriate context for national advertising" involved the creation of "an increasingly class-specific habitus" in which the "ideal reader" was constructed as white and professional (Sender 2001). "Not only is much recent gay visibility aimed at producing new and potentially lucrative markets, but as in most marketing strategies, money, not liberation, is the bottom line," Rosemary Hennessy has written. "The increasing circulation of gay and lesbian images in consumer culture has the effect of consolidating an imaginary, class-specific gay subjectivity for both straight and gay audiences" (1994-95, p. 32). Both the television visibility and the gay niche-marketing visibility emphasize-inaccurately, as by now several economists have demonstrated (Badgett 2001) - that gay men are at the very center of the upper middle class.

The notion that the virtue and value of gayness is found in class advantage is alarming and worth fighting, both for what it puts out and what it leaves out. There is, first of all, a huge gap between the cultural situation on television and the political situation outside of it. On television, gay men are treated as models of normality, and as cultural superiors; off television, lesbians and gay men remain excluded from many major social institutions and resources, and regular targets of hostility and violence. The celebratory cultural visibility can make it harder to see the very real political vulnerability.

The new gay visibility also seems to undercut some of the most promising traditions gay and lesbian people have come up with. There is, for instance, a long tradition in lesbian and gay life that proposes blurring the lines between gay and straight — not in order to become "normal," but in order to interrupt the very idea of the normal (Seidman 1996). That tradition sees gay people not 
as models of consumption but as models of social transformation and sexual freedom, offering the entire society different ways to integrate sexuality into one's life, different ways of building families, and so on. This sexual liberation tradition has its naïve aspects, and many lesbians, gay men, bisexuals, and transgendered people are much more interested in conventional lives; just because a way of life is institutionalized and ratified as normal does not mean it must be resisted. But it is nonetheless sad to note just how little of the liberationist tradition, with visions of social transformation and celebrations of nonconformity, is found in the new gay cultural visibility.

For the very reasons I have pointed to here, it is unrealistic to look to television to encourage and publicize much that challenges norms about sexuality, gender, consumption, class, and so on. But if television is one of the central places where a conversation is taking place about whether and how gay and straight people differ, it may be worth considering that its answers have more to do with television itself than with us.

\section{References}

Andreoli, Rick. 2003. "The Dating Game." The Advocate, July 4.

Badgett, M.V. Lee. 2001. Money, Myths, and Change: The Economic Lives of Lesbians and Gay Men. Chicago: University of Chicago Press.

Bravo TV, "Boy Meets Boy." Retrieved April 9, 2004 (http:// www.bravotv.com/Boy_Meets_Boy/).

Bravo TV, "Queer Eye for the Straight Guy." Retrieved April 9, 2004 (http://www.bravotv.com/Queer Eye for the Straight Guy/).

Chasin, Alexandra. 2000. Selling Out : The Gay and Lesbian Movement Goes to Market. New York: Palgrave.

Connell, R.W. 1987. Gender and Power: Society, the Person and Sexual Politics. Stanford: Stanford University Press.

Croteau, David and William Hoynes. 2001. The Business of Media Corporate Media and the Public Interest. Thousand Oaks, CA: Pine Forge Press.

della Cava, Marco. 2004. “'Queer Eye' Has Keen Eye for Sales.” USA Today, February 26, p. D5. 
Gamson, Joshua. 1998. Freaks Talk Back: Tabloid Talk Shows and Sexual Nonconformity. Chicago: University of Chicago Press.

Gamson, Joshua. 2002. "Sweating in the Spotlight: Lesbian, Gay, and Queer Encounters with Media and Popular Culture," in Steven Seidman and Diane Richardson, eds., Handbook of Lesbian and Gay Studies. Thousand Oaks, CA: Sage Publications.

Gitlin, Todd. 1993. Inside Prime Time. New York: Pantheon.

Gross, Larry. 2001. Up from Invisibility: Lesbians, Gay Men, and the Media in America. New York: Columbia University Press.

Hennessy, Rosemary. 1994-95. "Queer Visibility in Commodity Culture." Cultural Critique (Winter):31-75.

Herek, Gregory M. 2000. "The Psychology of Sexual Prejudice." Current Directions in Psychological Science, 9(1), 19-22.

Ricki Lake Show. 2003. "Metrosexuals: The New Ladies Man." September 18.

Rottnek, Matthew, ed. 1999. Sissies and Tomboys: Gender Nonconformity and Homosexual Childhood. New York: New York University Press.

Sender, Katherine. 2001. "Gay readers, consumers and a dominant gay habitus: 25 years of the Advocate magazine." Journal of Communication 51:73-99.

Sender, Katherine. 2004. Business, Not Politics: The Making of the Gay Market. New York: Columbia University Press.

Seidman, Steven, ed. 1996. Queer Theory/Sociology. Cambridge, MA: Blackwell.

Seidman, Steven. 2002. Beyond the Closet The Transformation of Gay and Lesbian Life. New York: Routledge.

Stanley, Alessandra. 2003. "On TV, Men Are the New Women." New York Times, September 28, p. B1.

Swidler, Ann, Melissa Rapp and Yasemin Soysal. 1986. "Format and formula in prime-time TV," in Sandra J. Ball-Rokeach and Muriel G. Cantor, eds., Media, Audience, and Social Structure. Beverly Hills, CA: Sage.

Walters, Suzanna Danuta. 2001. All the Rage: The Story of Gay Visibility in America. Chicago: University of Chicago Press.

Weinraub, Bernard and Jim Rutenberg. 2003. "Gay-themed TV Gaining a Wider Audience.” New York Times, July 29, p. A1. 